\title{
First-degree family history of breast cancer is associated with prostate cancer risk: a systematic review and meta-analysis
}

\author{
Zheng-Ju Ren ${ }^{1 \dagger}$, De-Hong Cao ${ }^{1,2+}$, Qin Zhang ${ }^{3}$, Peng-Wei Ren ${ }^{4}$, Liang-Ren Liu', Qiang Wei ${ }^{1}$, Wu-Ran Wei ${ }^{1}$ \\ and Qiang Dong ${ }^{1 *}$ (D)
}

\begin{abstract}
Background: The relationship between first-degree family history of female breast cancer and prostate cancer risk in the general population remains unclear. We performed a meta-analysis to determine the association between first-degree family history of female breast cancer and prostate cancer risk.

Methods: Databases, including MEDLINE, Embase, and Web of Science, were searched for all associated studies that evaluated associations between first-degree family history of female breast cancer and prostate cancer risk up to December 31, 2018. Information on study characteristics and outcomes were extracted based on the Preferred Reporting Items for Systematic Review and Meta-analysis (PRISMA) statement and Meta-analysis of Observational Studies in Epidemiology (MOOSE) guidelines. The quality of evidence was assessed using the GRADE approach.

Results: Eighteen studies involving 17,004,892 individuals were included in the meta-analysis. Compared with no family history of female breast cancer, history of female breast cancer in first-degree relatives was associated with an increased risk of prostate cancer [relative risk (RR) 1.18, 95\% confidence interval (CI) 1.12-1.25] with moderatequality evidence. A history of breast cancer in mothers only (RR 1.19,95\% Cl 1.10-1.28) and sisters only (RR 1.71, 95\% Cl 1.43-2.04) was associated with increased prostate cancer risk with moderate-quality evidence. However, a family history of breast cancer in daughters only was not associated with prostate cancer incidence (RR 1.74, 95\% Cl 0.74-4.12) with moderate-quality evidence. A family history of female breast cancer in first-degree relatives was associated with an $18 \%$ increased risk of lethal prostate cancer $(95 \% \mathrm{Cl} 1.04-1.34)$ with low-quality evidence.

Conclusions: This review demonstrates that men with a family history of female breast cancer in first-degree relatives had an increased risk of prostate cancer, including risk of lethal prostate cancer. These findings may guide screening, earlier detection, and treatment of men with a family history of female breast cancer in first-degree relatives.
\end{abstract}

Keywords: Prostate cancer, Breast cancer, Family history, Meta-analysis

\section{Background}

Prostate cancer is the second most common cancer and the fifth leading cause of death in men worldwide $[1,2]$. Cancer epidemiological data showed approximately 1,276, 106 new prostate cancer cases and almost 358,989 cancer deaths worldwide in 2018 [2]. The cause of prostate

\footnotetext{
* Correspondence: dong_qiang@mcwcums.com; dqiang666@163.com ${ }^{\dagger}$ Zheng-Ju Ren and De-Hong Cao are considered as co-first authors on this work.

${ }^{1}$ Department of Urology, Institute of Urology, West China Hospital, Sichuan University, 37, Guo Xue Road, Chengdu 610041, China

Full list of author information is available at the end of the article
}

cancer is complex and has not been fully determined. The possible risk factors are age, race, geography, family history, and genetic factors [3-5]. Among these risk factors, family history is a recognized risk factor for the development of prostate cancer [6, 7]. Patients with a family history of prostate cancer in first-degree relatives were 2.48 times more likely to develop prostate cancer than those without first-degree relatives with prostate cancer [8].

Approximately $35 \%$ of familial prostate cancer risk is explained by known genes $[9,10]$. BRCA1 and BRCA2 are two major predisposition genes that induce hereditary

(c) The Author(s). 2019 Open Access This article is distributed under the terms of the Creative Commons Attribution 4.0 International License (http://creativecommons.org/licenses/by/4.0/), which permits unrestricted use, distribution, and reproduction in any medium, provided you give appropriate credit to the original author(s) and the source, provide a link to the Creative Commons license, and indicate if changes were made. The Creative Commons Public Domain Dedication waiver (http://creativecommons.org/publicdomain/zero/1.0/) applies to the data made available in this article, unless otherwise stated. 
breast and ovarian cancer $[11,12]$. There is definite evidence that prostate cancer risk is increased in BRCA1 and BRCA2 mutation carriers ascertained by a family history of breast cancer [13]. BRCA1 mutation carriers increase the risk of prostate cancer in men aged $<65$ years by 3.8fold, and germline mutations in the BRCA2 gene increase prostate cancer risk by 8.6 -fold $[14,15]$. The mutation status of BRCA1/BRCA2 is closely related to the degree of prostate invasion, earlier death, and shorter survival time [15-17]. Moreover, previous observational studies have also reported that family history of breast cancer in firstdegree relatives is associated with prostate cancer, including lethal prostate cancer $[18,19]$.

Recently, controversy came from several large-scale, high-quality analyses that attempted to analyse whether there was a correlation between the first-degree family history of female breast cancer and risk of prostate cancer. To better understand this issue, we performed a systematic review with meta-analysis of published literature that investigated the association between first-degree family history of female breast cancer and risk of prostate cancer.

\section{Methods \\ Literature search and selection criteria}

A systematic search in MEDLINE, Embase, and Web of Science was performed from the earliest publication date available until December 31, 2018. Additional studies were searched by checking the reference lists of relevant studies. The following search terms were used: '(prostate cancer OR prostate carcinoma OR prostate neoplasm) AND (breast cancer OR breast carcinoma OR breast neoplasm) AND (family history)'.

Studies were considered eligible if they (1) were published in the English language; (2) had full text available; (3) evaluated the relationship between first-degree family history of female breast cancer and prostate cancer risk; (4) provided risk estimates with confidence intervals (CIs) or available data to calculate these associations;

PRISMA 2009 Flow Diagram

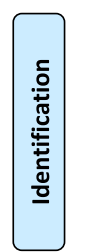

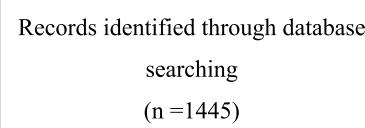

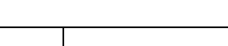

Additional records identified

through other sources

$(\mathrm{n}=0)$
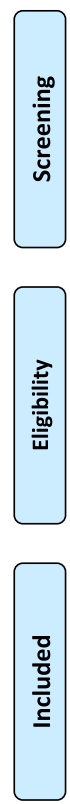
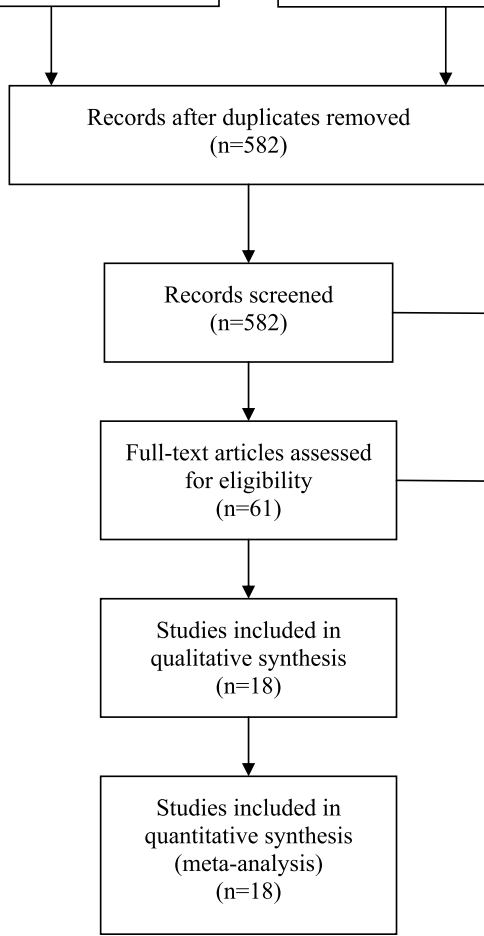

Records excluded:

Not relevant using title and

abstract $(n=521)$

Full-text articles excluded: Case report $(\mathrm{n}=2)$, Editorials $(\mathrm{n}=1)$, Insufficient data $(\mathrm{n}=5)$, not reporting prostate cancer risk $(\mathrm{n}=27)$, not reporting family history of breast cancer $(n=8)$

Fig. 1 Flow chart of study selection 
Table 1 Characteristics of studies included in the meta-analysis

\begin{tabular}{|c|c|c|c|c|c|c|c|c|c|}
\hline Author & Year & Country & Study disgn & $\begin{array}{l}\text { Follow up } \\
\text { duration }\end{array}$ & Sample size & Exposure & $\begin{array}{l}\text { Measure } \\
\text { of effect }\end{array}$ & $\begin{array}{l}\text { RR (prostae } \\
\text { cancer risk) } \\
(95 \% \text { Cl) }\end{array}$ & Adjustment factors \\
\hline \multirow[t]{3}{*}{ Tulinius } & \multirow[t]{3}{*}{1992} & \multirow[t]{3}{*}{ Iceland } & \multirow[t]{3}{*}{ Cohort } & \multirow[t]{3}{*}{ 1955-1988 } & \multirow[t]{3}{*}{29,725} & Mother with $\mathrm{BCa}$ & \multirow[t]{3}{*}{ RR } & $1.40(0.51,3.05)$ & \multirow[t]{3}{*}{-} \\
\hline & & & & & & Sister with $\mathrm{BCa}$ & & $1.29(0.9,1.79)$ & \\
\hline & & & & & & Daughter with BCa & & $1.45(1.02,2.00)$ & \\
\hline Goldgar & 1994 & USA & Cohort & 1952-1992 & 656,017 & $\begin{array}{l}\text { First degree relatives } \\
\text { with } \mathrm{BCa}\end{array}$ & $\mathrm{RR}$ & $1.23(1.1,1.3)$ & - \\
\hline \multirow[t]{3}{*}{ Hayes } & \multirow[t]{3}{*}{1995} & \multirow[t]{3}{*}{ USA } & \multirow[t]{3}{*}{ Case-control } & \multirow[t]{3}{*}{-} & \multirow[t]{3}{*}{$\begin{array}{l}\text { Case: } 981 \\
\text { Control: } 1315\end{array}$} & $\begin{array}{l}\text { First degree relatives } \\
\text { with } \mathrm{BCa}\end{array}$ & \multirow[t]{3}{*}{$\mathrm{OR}$} & $1.3(0.9,1.9)$ & \multirow{3}{*}{$\begin{array}{l}\text { Socio-economic status, } \\
\text { based upon usual } \\
\text { occupation,education, } \\
\text { income, and marital } \\
\text { status }\end{array}$} \\
\hline & & & & & & Mother with $\mathrm{BCa}$ & & $1.0(0.6,1.7)$ & \\
\hline & & & & & & Sister with $\mathrm{BCa}$ & & $1.8(1.1,3.0)$ & \\
\hline \multirow[t]{2}{*}{ Isaacs } & \multirow[t]{2}{*}{1995} & \multirow[t]{2}{*}{ USA } & \multirow[t]{2}{*}{ Case-control } & \multirow[t]{2}{*}{-} & \multirow{2}{*}{$\begin{array}{l}\text { Case: } 690 \\
\text { Control: } 683\end{array}$} & Mother with $\mathrm{BCa}$ & OR & $2.05(1.01,4.14)$ & \multirow[t]{2}{*}{ Age } \\
\hline & & & & & & Sister with $\mathrm{BCa}$ & OR & 1.53(0.78,3.00) & \\
\hline McCAHY & 1996 & UK & Case-control & - & $\begin{array}{l}\text { Case:209 } \\
\text { Control:322 }\end{array}$ & $\begin{array}{l}\text { First degree relatives } \\
\text { with } \mathrm{BCa}\end{array}$ & OR & $1.69(0.9,3.15)$ & - \\
\hline Glover & 1998 & Jamaica & Case-control & - & $\begin{array}{l}\text { Case: } 263 \\
\text { Control: } 263\end{array}$ & $\begin{array}{l}\text { First degree relatives } \\
\text { with } \mathrm{BCa}\end{array}$ & OR & $0.89(0.46,1.71)$ & - \\
\hline \multirow[t]{5}{*}{ Rodriguez } & \multirow[t]{5}{*}{1998} & \multirow[t]{5}{*}{ USA } & \multirow[t]{5}{*}{ Cohort } & \multirow[t]{5}{*}{ 1982-1994 } & \multirow[t]{5}{*}{480,802} & $\begin{array}{l}\text { First degree relatives } \\
\text { with } \mathrm{BCa}\end{array}$ & $\mathrm{RR}$ & $1.16(1.01,1.33)$ & $\begin{array}{l}\text { Age, race, years of } \\
\text { education, number }\end{array}$ \\
\hline & & & & & & Mother with $\mathrm{BCa}$ & & $1.34(1.11,1.62)$ & of sisters older than \\
\hline & & & & & & Sister with $\mathrm{BCa}$ & & $0.97(0.78,1.20)$ & 50 years of age, Jewish \\
\hline & & & & & & $\begin{array}{l}\text { History of } \mathrm{BCa} \\
\text { diagnosis at age }<50\end{array}$ & & $1.23(0.94,1.62)$ & $\begin{array}{l}\text { activity, vegetable and } \\
\text { fat intake, smoking }\end{array}$ \\
\hline & & & & & & $\begin{array}{l}\text { History of BCa } \\
\text { diagnosis at age }>50\end{array}$ & & $1.16(0.98,1.37)$ & $\begin{array}{l}\text { status, and previous } \\
\text { vasectomy }\end{array}$ \\
\hline Kalish & 2000 & USA & Cohort & 1987-1997 & 1156 & Mother with $\mathrm{BCa}$ & $\mathrm{RR}$ & $1.18(0.51,2.43)$ & - \\
\hline Bai & 2005 & China & Case-control & - & $\begin{array}{l}\text { Case:238 } \\
\text { Control:471 }\end{array}$ & $\begin{array}{l}\text { First degree relatives } \\
\text { with } \mathrm{BCa}\end{array}$ & OR & $2.04(0.75,5.51)$ & Age, vasectomy history \\
\hline & & & & & & Mother with $\mathrm{BCa}$ & & $2.01(0.28,14.38)$ & \\
\hline & & & & & & Sister with $\mathrm{BCa}$ & & $4.03(0.73,22.14)$ & \\
\hline & & & & & & Daughter with $\mathrm{BCa}$ & & $1.01(0.18,5.54)$ & \\
\hline Negri & 2005 & Italy & Case-control & - & $\begin{array}{l}\text { Case: } 1294 \\
\text { Control:2820 }\end{array}$ & $\begin{array}{l}\text { First degree relatives } \\
\text { with } \mathrm{BCa}\end{array}$ & OR & $1.20(0.8,1.8)$ & $\begin{array}{l}\text { Age, study centre, period } \\
\text { of interview, education, } \\
\text { occupational physical } \\
\text { activity at } 30-39 \text { years } \\
\text { of age and no of siblings } \\
\text { (or sisters or brothers } \\
\text { when appropriate) }\end{array}$ \\
\hline Beebe- & 2006 & USA & Case-control & - & Case:121 & Mother with $\mathrm{BCa}$ & OR & $0.52(0.10,2.69)$ & Age \\
\hline Dimmer & & & & & Control:1/9 & Sister with $\mathrm{BCa}$ & & $3.80(1.57-9.22)$ & \\
\hline & & & & & & Daughter with BCa & & $1.01(0.19-5.28)$ & \\
\hline Suzuki & 2007 & Japan & Case-control & - & $\begin{array}{l}\text { Case: } 257 \\
\text { Control: } 28,125\end{array}$ & $\begin{array}{l}\text { First degree relatives } \\
\text { with } \mathrm{BCa}\end{array}$ & OR & $3.6(1.1-11.7)$ & $\begin{array}{l}\text { Smoking history, drinking, } \\
\text { BMI, exercise habit, and } \\
\text { referral pattern to the } \\
\text { hospital }\end{array}$ \\
\hline Chen & 2008 & USA & Cohort & 1986-2004 & 51,529 & $\begin{array}{l}\text { First degree relatives } \\
\text { with } \mathrm{BCa}\end{array}$ & $\mathrm{RR}$ & $1.30(1.13,1.49)$ & $\begin{array}{l}\text { Ethnicity, BMI, total } \\
\text { calories, vigorous activity, }\end{array}$ \\
\hline & & & & & & Mother with $\mathrm{BCa}$ & & $1.24(1.06,1.45)$ & $\begin{array}{l}\text { Clgarette smoking, and } \\
\text { consumption of tomato }\end{array}$ \\
\hline & & & & & & Sister with $\mathrm{BCa}$ & & $1.19(0.98,1.45)$ & $\begin{array}{l}\text { sauce, calcium, alpha } \\
\text { linolenic fatty acid, fish, } \\
\text { and red meat }\end{array}$ \\
\hline Mori & 2011 & Japan & Case-control & - & Case:142 & Mother or sister & OR & $2.70(1.12,6.49)$ & - \\
\hline
\end{tabular}


Table 1 Characteristics of studies included in the meta-analysis (Continued)

\begin{tabular}{|c|c|c|c|c|c|c|c|c|c|}
\hline Author & Year & Country & Study disgn & $\begin{array}{l}\text { Follow up } \\
\text { duration }\end{array}$ & Sample size & Exposure & $\begin{array}{l}\text { Measure } \\
\text { of effect }\end{array}$ & $\begin{array}{l}\text { RR (prostae } \\
\text { cancer risk) } \\
(95 \% \text { Cl) }\end{array}$ & Adjustment factors \\
\hline & & & & & Control:468 & with $\mathrm{BCa}$ & & & \\
\hline \multirow[t]{3}{*}{ Thomas II } & \multirow[t]{3}{*}{2012} & \multirow[t]{3}{*}{ USA } & \multirow[t]{3}{*}{ Cross section } & \multirow[t]{3}{*}{-} & \multirow[t]{3}{*}{8122} & $\begin{array}{l}\text { Frist degree relatives } \\
\text { with } \mathrm{BCa}\end{array}$ & \multirow[t]{3}{*}{ OR } & $1.04(0.84,1.29)$ & \multirow{3}{*}{$\begin{array}{l}\text { Age, race, PSA, BMI, } \\
\text { TRUS volume, } \\
\text { geographic region, } \\
\text { DRE findings and } \\
\text { treatment arm }\end{array}$} \\
\hline & & & & & & Mother with $\mathrm{BCa}$ & & $1.07(0.8,1.42)$ & \\
\hline & & & & & & Sister with $\mathrm{BCa}$ & & $1.30(0.95,1.78)$ & \\
\hline Frank & 2017 & Sweden & Cohort & 1958-2012 & $15,700,000$ & $\begin{array}{l}\text { Frist degree relatives } \\
\text { with } \mathrm{BCa}\end{array}$ & $\mathrm{RR}$ & $1.12(1.08,1.16)$ & $\begin{array}{l}\text { Sex, age group, } \\
\text { calendar period, } \\
\text { residential area, and } \\
\text { socioeconomic status }\end{array}$ \\
\hline \multirow[t]{3}{*}{ Barber } & \multirow[t]{3}{*}{2018} & \multirow[t]{3}{*}{ USA } & \multirow[t]{3}{*}{ Cohort } & \multirow[t]{3}{*}{ 1996-2012 } & \multirow[t]{3}{*}{37,002} & $\begin{array}{l}\text { Frist degree relatives } \\
\text { with } \mathrm{BCa}\end{array}$ & \multirow[t]{3}{*}{$\mathrm{HR}$} & $1.21(1.1,1.34)$ & \multirow{3}{*}{$\begin{array}{l}\text { Age, race, BMI, } \\
\text { smoking status, PSA } \\
\text { screening, PSA testing } \\
\text { intensity, alcohol intake, } \\
\text { vigorous physical activity, } \\
\text { total energy intake, } \\
\text { consumption of tomato } \\
\text { sauce, and red meat }\end{array}$} \\
\hline & & & & & & Mother with $\mathrm{BCa}$ & & $1.14(1.01,1.27)$ & \\
\hline & & & & & & Sister with $\mathrm{BCa}$ & & $1.20(1.04,1.39)$ & \\
\hline \multirow[t]{6}{*}{ Lamy } & \multirow[t]{6}{*}{2018} & \multirow[t]{6}{*}{ France } & \multirow[t]{6}{*}{ Case-control } & \multirow[t]{6}{*}{-} & \multirow[t]{6}{*}{$\begin{array}{l}\text { Case:819 } \\
\text { Control:879 }\end{array}$} & $\begin{array}{l}\text { First degree relatives } \\
\text { with } \mathrm{BCa}\end{array}$ & \multirow[t]{6}{*}{ OR } & $1.13(0.84,1.52)$ & \multirow{6}{*}{$\begin{array}{l}\text { Age, ethnic origin, } \\
\text { number of first-degree } \\
\text { female relatives and } \\
\text { famili history of prostate } \\
\text { cancer in first-degree } \\
\text { relatives }\end{array}$} \\
\hline & & & & & & Mother with $\mathrm{BCa}$ & & $1.04(0.71,1.52)$ & \\
\hline & & & & & & Sister with $\mathrm{BCa}$ & & $1.10(0.72,1.68)$ & \\
\hline & & & & & & Daughter with $\mathrm{BCa}$ & & $15.26(1.95,120)$ & \\
\hline & & & & & & $\begin{array}{l}\text { History of BCa } \\
\text { diagnosis at age }<50\end{array}$ & & $1.79(1.09,2.94)$ & \\
\hline & & & & & & $\begin{array}{l}\text { History of BCa } \\
\text { diagnosis at age }>50\end{array}$ & & $0.88(0.61,1.27)$ & \\
\hline
\end{tabular}

BCa: breast cancer; PCa: prostate cancer; RR: Relative risk; OR: odds ratio; HR: hazard ratio

and (5) were cohort, cross-sectional, and case-control studies.

\section{Data extraction and quality assessment}

Two investigators independently extracted data using a standard data collection form. The data extracted from each study included the following: first author, publication year, study design, country of the study population, sample size, reported primary outcome, follow-up duration, hazard ratio or odds ratio, and relative risk and 95\% confidence intervals (CIs) with and without adjustment and adjustment factors.

Two independent reviewers evaluated the quality of the included studies according to the Newcastle-Ottawa scale (NOS) [20]. The scale uses a 'star' rating system (maximum nine stars) to assess the quality of case-control and cohort studies including three aspects: selection of participants, comparability of study groups, and ascertainment of outcomes of interest [20]. If the study scored nine stars, it was considered to be of high quality. Studies with a score of seven or eight stars were considered to be of medium quality. However, if a study scored less than seven stars, it was considered to be of low quality. Any discrepancies in opinions were resolved by discussion with a third author.
Table 2 Quality assessment of included studies

\begin{tabular}{|c|c|c|c|c|c|}
\hline Author & Year & Selection & Comparability & Exposure & Total \\
\hline Tulinius & 1992 & $\star \star \star \star$ & $\star \star$ & $\star \star$ & 7 \\
\hline Goldgar & 1994 & $\star \star \star$ & $\star \star$ & $\star \star$ & 7 \\
\hline Hayes & 1995 & $\star \star \star \star$ & $\star \star$ & $\star \star$ & 7 \\
\hline Isaacs & 1995 & $\star \star$ & $\star \star$ & $\star \star$ & 6 \\
\hline MCCAHY & 1996 & $\star \star$ & $\star$ & $\star \star \star \star$ & 6 \\
\hline Glover & 1998 & $\star \star$ & $\star \star$ & $\star \star$ & 6 \\
\hline Rodriguez & 1998 & $\star \star \star$ & $\star \star$ & $\star \star \star \star$ & 8 \\
\hline Kalish & 2000 & $\star \star \star$ & $\star \star$ & $\star \star$ & 7 \\
\hline Bai & 2005 & $\star \star$ & $\star \star$ & $\star \star$ & 6 \\
\hline Negri & 2005 & $\star \star \star$ & $\star \star$ & $\star \star$ & 7 \\
\hline Beebe-Dimmer & 2006 & $\star \star$ & $\star \star$ & $\star \star$ & 6 \\
\hline Suzuki & 2007 & $\star \star$ & $\star \star$ & $\star \star$ & 6 \\
\hline Chen & 2008 & $\star \star$ & $\star \star$ & $\star \star \star \star$ & 7 \\
\hline Mori & 2011 & $\star \star \star \star$ & $\star \star$ & $\star \star$ & 7 \\
\hline Frank & 2017 & $\star \star \star$ & $\star \star$ & $\star \star \star \star$ & 8 \\
\hline Barber & 2018 & $\star \star \star$ & $\star \star$ & $\star \star \star \star$ & 8 \\
\hline Lamy & 2018 & $\star \star \star$ & $\star \star$ & 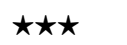 & 8 \\
\hline
\end{tabular}




\section{Grading the quality of evidence}

The quality of evidence for outcomes was evaluated by two investigators independently using GRADEpro Guideline Development Tool (McMaster University, 2015, developed by Evidence Prime Inc., Hamilton, Canada; https://gradepro.org/). The quality of evidence was evaluated according to risk of bias, inconsistency, indirectness, imprecision of the results, and publication bias. The quality of evidence for the main outcome was classified into four grades: very low, low, moderate, and high.

\section{Statistical analysis}

The primary outcome was relative risks for prostate cancer incidence. Subgroup analyses of the primary outcome were conducted based on the study design, region, and quality (adjustment vs no adjustment). For each study, risk ratio for prostate cancer with the $95 \%$ CI was computed. The random effects model was used to compute the pooled risk ratio. Heterogeneity between studies was evaluated using the chi-square-based $\mathrm{Q}$ test and $\mathrm{I}^{2}$ metric. If $P<0.10$ and $\mathrm{I}^{2}>50 \%$, the heterogeneity was considered statistically significant. The significance of the summary RR was assessed using the Z-test, and a $P$ value $<0.05$ was considered as statistically significant. A sensitivity analysis was conducted to evaluate the stability of the results by excluding individual studies each time. Funnel plots and Begg's and Egger's tests were used to investigate the potential publication bias. All statistical analyses were conducted using Stata software version 12.0 (Stata Corporation, College Station, Texas, USA).

\section{Results \\ Retrieved studies and characteristics}

The systematic search of articles published before December 31, 2018, identified 1554 articles. After screening titles and abstracts, we obtained 61 study reports for full-text review. After a full-text review, we finally included 18 published reports comprising 17,004,892 individuals for analysis [19, 21-37] (Fig. 1). Overall, six were cohort studies, 11 were case-control studies, and one was a cross-sectional study. Ten of these studies were based in America, 5 in Europe, and 3 in Asia. A history of breast cancer in first-degree relatives was reported in 13 studies, in mothers only in 11 studies, and in sisters only in 10 studies. The articles were published between 1992 and 2018. The detailed characteristics of all included studies are shown in Table 1 . The quality of studies based on the NOS score is presented in Table 2 . Most studies were of medium to high quality (score $\geq 7$ ). Six case-control studies were of low quality.

\section{Associations between family history of breast cancer and risk of prostate cancer}

Eighteen studies with $17,004,892$ individuals in total evaluated the association between family history of breast cancer and risk of prostate cancer. Of these, 13 studies with a total of 16,971,728 individuals evaluated the association between family history of female breast

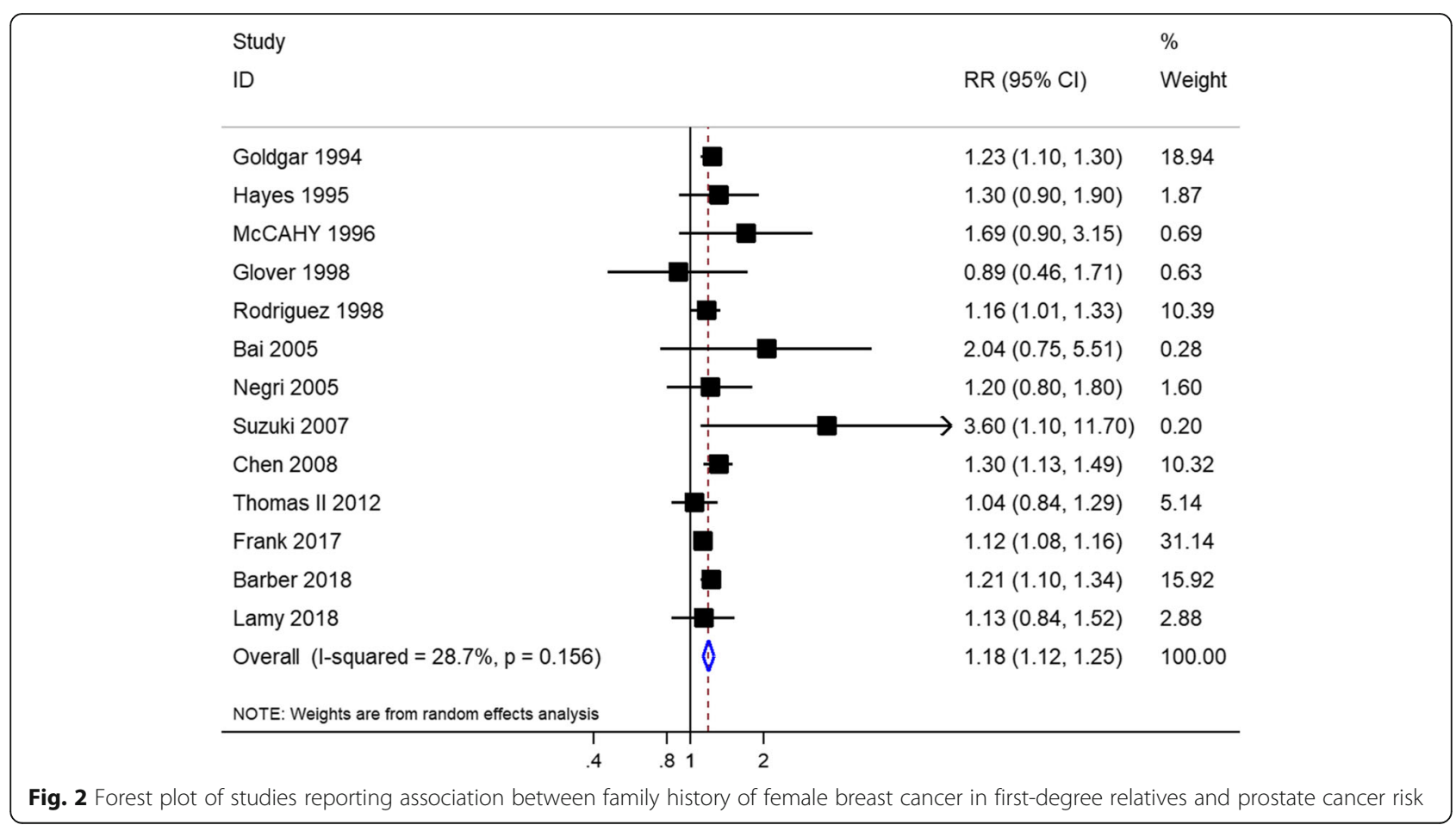


cancer in first-degree relatives and risk of prostate cancer. The history of female breast cancer in first-degree relatives was significantly associated with prostate cancer risk $\left(\mathrm{RR}=1.18,95 \% \mathrm{CI}=1.12-1.25, \mathrm{I}^{2}=28.70 \%\right)$ (Fig. 2$)$, with moderate-quality evidence (Table 3 ). This increased risk with family history of female breast cancer persisted in studies that adjusted for potential confounders (adjusted RR, 1.17; 95\% CI, 1.10-1.24; $\mathrm{I}^{2}=25.30 \%$ ) (Table 4). When we stratified our analysis by study design, a significantly increased association was observed in the pooled cohort studies (RR, 1.17; 95\% CI, 1.10-1.25; $\mathrm{I}^{2}=48.90 \%$ ) and pooled case-control studies (RR, 1.23; 95\% CI, 1.141.33; $\mathrm{I}^{2}=0.00 \%$ ) (Table 4). Subgroup analyses based on the study region showed that a family history of female breast cancer was significantly associated with prostate cancer risk in America, Europe, and Asia (Table 4). Moreover, this increased prostate cancer risk was not observed in first-degree relatives with a breast cancer diagnosis at age $<50$ years $\left(\mathrm{RR}=1.40,95 \% \mathrm{CI}=0.99-1.98, \mathrm{I}^{2}=40.00 \%\right)$ and $\geq 50 \quad\left(\mathrm{RR}=1.06, \quad 95 \% \quad \mathrm{CI}=0.83-1.37, \mathrm{I}^{2}=45.00 \%\right)$ (Table 4).

A history of breast cancer in mothers only was reported in 11 studies (614,712 participants). A family history of breast cancer in mothers only was associated with prostate cancer incidence $(\mathrm{RR}=1.19,95 \% \mathrm{CI}=$ $1.10-1.28, \mathrm{I}^{2}=0.00 \%$ ) with moderate-quality evidence (Fig. 3, Table 3). This increased risk with family history of breast cancer persisted in studies that adjusted for potential confounders (adjusted RR, 1.19; 95\% CI, 1.10$1.28 ; \mathrm{I}^{2}=0.10 \%$ ) (Table 4 ). When we stratified our analysis by study design, there was a statistically significant increased association in the five pooled cohort studies (RR, 1.21; 95\% CI, 1.11-1.31; $\mathrm{I}^{2}=0.00 \%$ ), but no association between history of breast cancer in mothers only and prostate cancer risk was observed in the five pooled case-control studies $\left(\mathrm{RR}=1.14,95 \% \mathrm{CI}=0.85-1.54, \mathrm{I}^{2}=\right.$ $7.30 \%$ ) (Table 4). Subgroup analyses based on the study region showed that a statistically significant increased association between history of breast cancer in mothers only and prostate cancer risk was observed in America, but not in Europe and Asia (Table 4).

A history of breast cancer in sisters only was reported in 10 studies (613,556 participants). A family history of breast cancer in sisters was associated with prostate cancer $\left(\mathrm{RR}=1.25,95 \% \mathrm{CI}=1.09-1.44, \mathrm{I}^{2}=43.00 \%\right)$ with moderate-quality evidence (Fig. 3, Table 3). This

Table 3 GRADE assessment of quality of the body of evidence, and summary of findings

\begin{tabular}{|c|c|c|c|c|c|c|c|c|c|}
\hline Association studied & $\begin{array}{l}\text { No. of } \\
\text { studies }\end{array}$ & Design & $\begin{array}{l}\text { Risk of } \\
\text { bias }\end{array}$ & Inconsistency & Indirectness & Imprecision & $\begin{array}{l}\text { Factors that can } \\
\text { increase quality } \\
\text { of evidence }\end{array}$ & $\begin{array}{l}\text { Pooled effect } \\
\text { estimate }\end{array}$ & Quality \\
\hline $\begin{array}{l}\text { Family history of } \\
\mathrm{BCa} \text { in first degree } \\
\text { relatives and risk } \\
\text { of } \mathrm{PCa}\end{array}$ & 13 & $\begin{array}{l}\text { Observational } \\
\text { study }\end{array}$ & $\begin{array}{l}\text { Not } \\
\text { serious }\end{array}$ & Not serious & Not serious & Not serious & $\begin{array}{l}\text { All plausible } \\
\text { confounding } \\
\text { would reduce } \\
\text { a demonstrated } \\
\text { effect }\end{array}$ & $\begin{array}{l}1.14(1.10 \\
1.18)\end{array}$ & $\bigoplus \oplus \oplus O M O D E R A T E$ \\
\hline $\begin{array}{l}\text { Family history of } \mathrm{BCa} \\
\text { in mothers and risk } \\
\text { of } \mathrm{PCa}\end{array}$ & 11 & $\begin{array}{l}\text { Observational } \\
\text { study }\end{array}$ & $\begin{array}{l}\text { Not } \\
\text { serious }\end{array}$ & Not serious & Not serious & Not serious & $\begin{array}{l}\text { All plausible } \\
\text { confounding } \\
\text { would reduce } \\
\text { a demonstrated } \\
\text { effect }\end{array}$ & $\begin{array}{l}1.19(1.10 \\
1.28)\end{array}$ & $\oplus \oplus \oplus O M O D E R A T E$ \\
\hline $\begin{array}{l}\text { Family history of } \mathrm{BCa} \\
\text { in sisters and risk of } \\
\text { PCa }\end{array}$ & 10 & $\begin{array}{l}\text { Observational } \\
\text { study }\end{array}$ & $\begin{array}{l}\text { Not } \\
\text { serious }\end{array}$ & Not serious & Not serious & Not serious & $\begin{array}{l}\text { All plausible } \\
\text { confounding } \\
\text { would reduce } \\
\text { a demonstrated } \\
\text { effect }\end{array}$ & $\begin{array}{l}1.16(1.06 \\
1.27)\end{array}$ & $\oplus \oplus \oplus O M O D E R A T E$ \\
\hline $\begin{array}{l}\text { Family history of } \mathrm{BCa} \\
\text { in daughters and risk } \\
\text { of } \mathrm{PCa}\end{array}$ & 4 & $\begin{array}{l}\text { Observational } \\
\text { study }\end{array}$ & $\begin{array}{l}\text { Not } \\
\text { serious }\end{array}$ & Not serious & Not serious & Not serious & $\begin{array}{l}\text { All plausible } \\
\text { confounding } \\
\text { would reduce } \\
\text { a demonstrated } \\
\text { effect }\end{array}$ & $\begin{array}{l}1.74(0.74 \\
1.42)\end{array}$ & $\oplus \oplus \oplus O M O D E R A T E$ \\
\hline $\begin{array}{l}\text { Family history of } \\
\mathrm{BCa} \text { in first degree } \\
\text { relatives and risk of } \\
\text { lethal } \mathrm{PCa}\end{array}$ & 2 & $\begin{array}{l}\text { Observational } \\
\text { study }\end{array}$ & $\begin{array}{l}\text { Not } \\
\text { serious }\end{array}$ & Not serious & Not serious & Not serious & None & $\begin{array}{l}1.18(1.04 \\
1.34)\end{array}$ & $\oplus \oplus \circ$ ○LOW \\
\hline $\begin{array}{l}\text { Family history of } \mathrm{BCa} \\
\text { in mothers and risk } \\
\text { of lethal PCa }\end{array}$ & 2 & $\begin{array}{l}\text { Observational } \\
\text { study }\end{array}$ & $\begin{array}{l}\text { Not } \\
\text { serious }\end{array}$ & Not serious & Not serious & Not serious & None & $\begin{array}{l}1.35(1.14 \\
1.61)\end{array}$ & $\oplus \oplus \circ \mathrm{OLOW}$ \\
\hline $\begin{array}{l}\text { Family history of } \mathrm{BCa} \\
\text { in sisters and risk of } \\
\text { lethal PCa }\end{array}$ & 2 & $\begin{array}{l}\text { Observational } \\
\text { study }\end{array}$ & $\begin{array}{l}\text { Not } \\
\text { serious }\end{array}$ & Not serious & Not serious & Not serious & None & $\begin{array}{l}1.02(0.84 \\
1.23)\end{array}$ & $\oplus \oplus \circ \mathrm{OLOW}$ \\
\hline
\end{tabular}


Table 4 Subgroup analysis for studies included in the analysis

\begin{tabular}{|c|c|c|c|c|}
\hline Prostate cancer risk & No. of studies & Pooled RR (95\% Cl) & $\mathrm{I}^{2}$ statistics (\%) & $P$-value for the heterogeneity $Q$ test \\
\hline First degree relatives with $\mathrm{BCa}$ & 13 & $1.18(1.12,1.25)$ & $28.70 \%$ & 0.156 \\
\hline Cohort & 5 & $1.19(1.12,1.26)$ & $53.70 \%$ & 0.071 \\
\hline Case-control & 7 & $1.26(1.04,1.53)$ & $6.90 \%$ & 0.375 \\
\hline Cross section & 1 & $1.04(0.84,1.29)$ & - & - \\
\hline European & 4 & $1.12(1.08,1.16)$ & $0.00 \%$ & 0.624 \\
\hline American & 7 & $1.21(1.15,1.27)$ & $0.00 \%$ & 0.618 \\
\hline Asian & 2 & $2.58(1.21,5.54)$ & $0.00 \%$ & 0.472 \\
\hline \multicolumn{5}{|l|}{ Adjustment for other factors } \\
\hline Yes & 10 & $1.17(1.10,1.24)$ & $25.30 \%$ & 0.210 \\
\hline No & 3 & $1.23(1.13,1.34)$ & $0.00 \%$ & 0.383 \\
\hline $\mathrm{BCa}$ diagnosis at age $\geq 50$ & 2 & $1.06(0.83,1.37)$ & $45.00 \%$ & 0.179 \\
\hline BCa diagnosis at age $<50$ & 2 & $1.40(0.99,1.98)$ & $40.00 \%$ & 0.195 \\
\hline Mother with $\mathrm{BCa}$ & 11 & $1.19(1.10,1.28)$ & $0.00 \%$ & 0.686 \\
\hline Cohort & 5 & $1.21(1.11,1.31)$ & $0.00 \%$ & 0.671 \\
\hline Case-control & 5 & $1.14(0.85,1.54)$ & $7.30 \%$ & 0.365 \\
\hline Cross section & 1 & $1.07(0.80,1.43)$ & - & - \\
\hline European & 2 & $1.09(0.77,1.54)$ & $0.00 \%$ & 0.549 \\
\hline American & 8 & $1.19(1.10,1.29)$ & $0.00 \%$ & 0.480 \\
\hline Asian & 1 & $2.01(0.28,14.40)$ & - & - \\
\hline \multicolumn{5}{|l|}{ Adjustment for other factors } \\
\hline Yes & 8 & $1.19(1.10,1.28)$ & $0.10 \%$ & 0.428 \\
\hline No & 3 & $1.32(0.75,2.32)$ & $0.00 \%$ & 0.873 \\
\hline Sister with $\mathrm{BCa}$ & 10 & $1.25(1.09,1.44)$ & $43.00 \%$ & 0.071 \\
\hline Cohort & 4 & $1.15(1.04,1.28)$ & $8.40 \%$ & 0.351 \\
\hline Case-control & 5 & $1.75(1.14,2.70)$ & $50.00 \%$ & 0.091 \\
\hline Cross section & 1 & $1.30(0.95,1.78)$ & - & - \\
\hline European & 2 & $1.21(0.93,1.58)$ & $0.00 \%$ & 0.567 \\
\hline American & 7 & $1.26(1.07,1.50)$ & $55.60 \%$ & 0.035 \\
\hline Asian & 1 & 4.03(0.73,22.19) & - & - \\
\hline \multicolumn{5}{|l|}{ Adjustment for other factors } \\
\hline Yes & 8 & $1.24(1.06,1.44)$ & $48.80 \%$ & 0.057 \\
\hline No & 2 & $1.66(0.66,4.18)$ & $39.20 \%$ & 0.200 \\
\hline Daughter with BCa & 4 & $1.74(0.74,4.12)$ & $43.70 \%$ & 0.149 \\
\hline Cohort & 1 & $1.45(1.04,2.03)$ & $8.40 \%$ & 0.351 \\
\hline Case-control & 3 & $2.27(0.44,11.75)$ & $62.50 \%$ & 0.046 \\
\hline European & 2 & $3.74(0.39,35.97)$ & $79.50 \%$ & 0.027 \\
\hline American & 1 & $1.01(0.19,5.28)$ & - & - \\
\hline Asian & 1 & $1.01(0.18,5.54)$ & - & - \\
\hline \multicolumn{5}{|l|}{ Adjustment for other factors } \\
\hline Yes & 2 & $3.66(0.26,52.14)$ & $75.30 \%$ & 0.044 \\
\hline No & 2 & $1.43(1.03,1.99)$ & $0.00 \%$ & 0.685 \\
\hline
\end{tabular}

BCa: breast cancer; PCa: prostate cancer 


\begin{tabular}{|c|c|c|}
\hline $\begin{array}{l}\text { Study } \\
\text { ID }\end{array}$ & $\mathrm{RR}(95 \% \mathrm{Cl})$ & $\begin{array}{l}\% \\
\text { Weight }\end{array}$ \\
\hline \multicolumn{3}{|l|}{ History of $\mathrm{BCa}$ in mother } \\
\hline Tulinius 1992 & $1.40(0.51,3.05)$ & 0.72 \\
\hline Hayes 1995 & $1.00(0.60,1.70)$ & 2.13 \\
\hline Isaacs 1995 & $2.05(1.01,4.14)$ & 1.16 \\
\hline Rodriguez 1998 & $1.34(1.11,1.62)$ & 16.15 \\
\hline Kalish 2000 & $1.18(0.51,2.43)$ & 0.95 \\
\hline Bai 2005 & $2.01(0.28,14.38)$ & 0.15 \\
\hline Beebe-Dimmer 2006 & $0.52(0.10,2.69)$ & 0.21 \\
\hline Chen 2008 & $1.24(1.06,1.45)$ & 23.52 \\
\hline Thomas II 2012 & $1.07(0.80,1.42)$ & 7.01 \\
\hline Barber 2018 & $1.14(1.01,1.27)$ & 44.00 \\
\hline Lamy 2018 & $1.04(0.71,1.52)$ & 3.98 \\
\hline Subtotal (I-squared $=0.0 \%, p=0.686$ ) & $1.19(1.10,1.28)$ & 100.00 \\
\hline \multicolumn{3}{|l|}{ History of $\mathrm{BCa}$ in sister } \\
\hline Tulinius 1992 & $1.29(0.90,1.79)$ & 10.48 \\
\hline Hayes 1995 & $1.80(1.10,3.00)$ & 6.12 \\
\hline Isaacs 1995 & $1.53(0.78,3.00)$ & 3.75 \\
\hline Rodriguez 1998 & $0.97(0.78,1.20)$ & 17.01 \\
\hline Bai 2005 & $4.03(0.73,22.14)$ & 0.66 \\
\hline Beebe-Dimmer 2006 & $3.80(1.57,9.22)$ & 2.30 \\
\hline Chen 2008 & $1.19(0.98,1.45)$ & 18.28 \\
\hline Thomas II 2012 & $1.30(0.95,1.78)$ & 11.71 \\
\hline Barber 2018 & $1.20(1.04,1.39)$ & 21.80 \\
\hline Lamy 2018 & $1.10(0.72,1.68)$ & 7.90 \\
\hline Subtotal $(I-$ squared $=43.0 \%, p=0.071)$ & $1.25(1.09,1.44)$ & 100.00 \\
\hline \multicolumn{3}{|l|}{ History of $\mathrm{BCa}$ in daughter } \\
\hline Tulinius 1992 & $1.45(1.02,2.00)$ & 51.29 \\
\hline Bai 2005 & $1.01(0.18,5.54)$ & 17.35 \\
\hline Beebe-Dimmer 2006 & $1.01(0.19,5.28)$ & 18.08 \\
\hline Lamy 2018 & $15.26(1.95,120.00)$ & 13.28 \\
\hline Subtotal (I-squared $=43.7 \%, p=0.149$ ) & $1.74(0.74,4.12)$ & 100.00 \\
\hline NOTE: Weights are from random effects analys & & \\
\hline
\end{tabular}

Fig. 3 Forest plot of studies reporting association between family history of female breast cancer and prostate cancer risk by source of family history

increased risk with family history of breast cancer persisted in studies that adjusted for potential confounders (adjusted RR, 1.24; 95\% CI, 1.06-1.44; $\mathrm{I}^{2}=48.80 \%$ ) (Table 4). Subgroup analyses based on the study design showed that a consistent result was observed in the pooled cohort studies (RR, 1.15; 95\% CI, 1.04-1.28; $\mathrm{I}^{2}=$ $8.40 \%)$ and pooled case-control studies (RR, 1.75; 95\% CI, 1.14-2.70; $\mathrm{I}^{2}=50.00 \%$ ) (Table 4 ). When we stratified our analysis by the study region, there was a statistically significant association in America, but no association between history of breast cancer in sisters only and prostate cancer risk in Europe and Asia (Table 4).

A history of breast cancer in daughters only was reported in 4 studies (32,432 participants). A family history of breast cancer in daughters only was not associated with prostate cancer $\left(\mathrm{RR}=1.74,95 \% \mathrm{CI}=0.74-4.12, \mathrm{I}^{2}=43.70 \%\right)$ with moderate-quality evidence (Fig. 3, Table 3). Similarly, no increased risk with family history of breast cancer in daughters only was observed in studies that adjusted for potential confounders (RR, 3.66; 95\% CI, 0.26-52.14; $\mathrm{I}^{2}=75.30 \%$ ) (Table 4). Subgroup analyses based on the study design showed that a statistically significant increased association between history of breast cancer in daughters only and prostate cancer risk was observed in cohort studies, but not in case-control studies (Table 4). When we stratified our analysis by study region, no significant association was observed in America, Europe, and Asia (Table 4).

\section{Associations between family history of female breast cancer and risk of lethal prostate cancer}

Two studies, including a total of 517,804 individuals, evaluated the association between family history of female breast cancer and risk of lethal prostate cancer. There was no significant heterogeneity among the studies $\left(\mathrm{I}^{2}=\right.$ $0.00 \%$ ). The increased risk of lethal prostate cancer was observed in individuals with family history of female breast cancer in first-degree relatives and in mothers only; however, no association was found between family history of breast cancer in sisters only and risk of lethal prostate cancer, with low-quality evidence (Fig. 4).

\section{Sensitivity analysis and publication bias}

A sensitivity analysis was conducted for prostate cancer risk by excluding individual studies each time, and the 


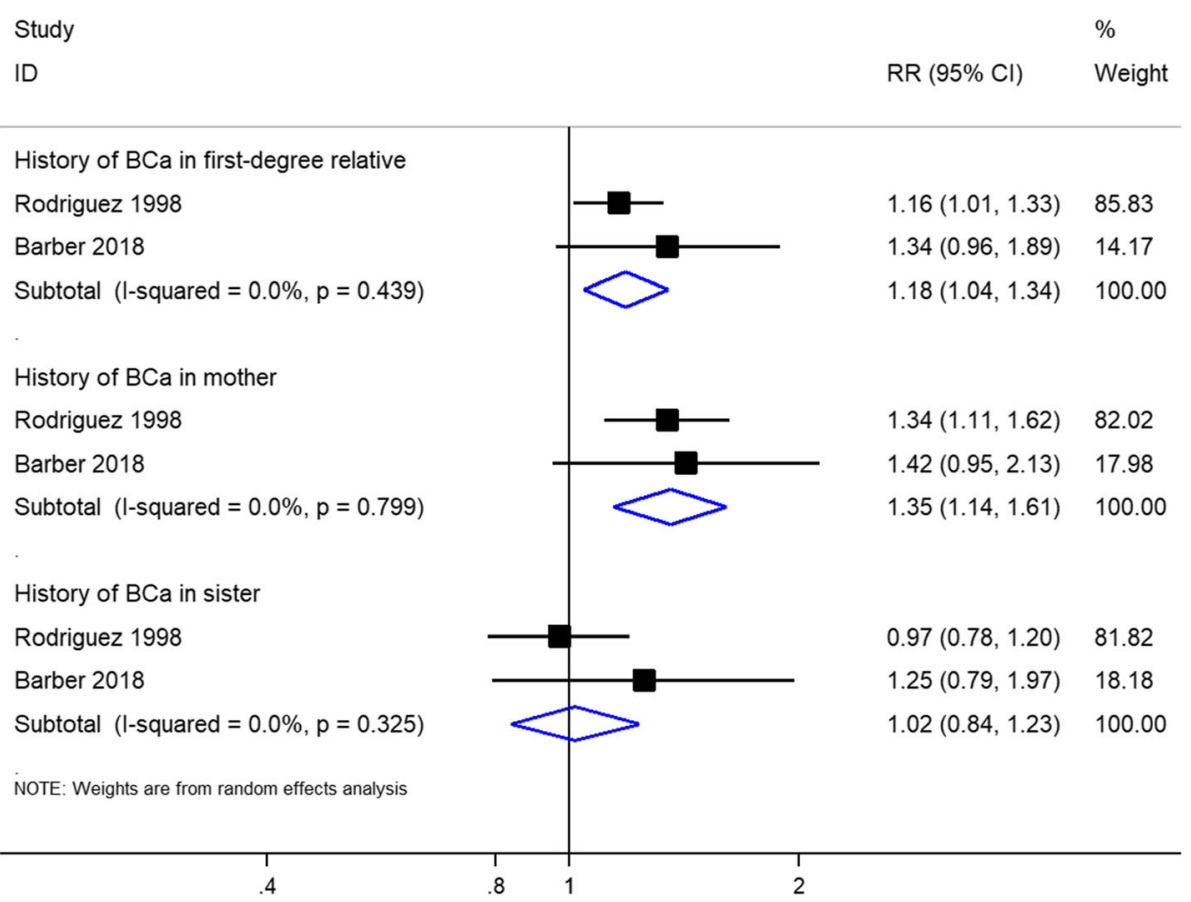

Fig. 4 Forest plot of studies reporting association between family history of female breast cancer and lethal prostate cancer risk

results showed no individual study influenced the overall RRs (Fig. 5), indicating the results of this meta-analysis are relatively stable. Some publication bias for the history of breast cancer in sisters only was observed in the results based on Egger's tests $(P=0.037)$ and funnel plots (Table 5, Fig. 6). No publication bias was observed based on visual inspection of funnel plots or Begg's and Egger's test for history of female breast cancer in firstdegree relatives and mothers only (Table 5, Fig. 6).

\section{Discussion}

Eighteen studies involving 17,004,892 participants met the inclusion criteria and were eventually included in our meta-analysis. The findings of this review suggest that prostate cancer risk was increased in individuals with a family history of female breast cancer in first-degree relatives, in mothers only and sisters only. Importantly, we observed increased lethal prostate cancer risks in individuals with family history of female breast cancer in first-degree relatives and mothers only, but not in sisters only. These findings are of great significance because the underlying pathogenesis of prostate cancer is still unknown and may help in screening, earlier diagnosis, and management of prostate cancer.

Prostate cancer pathogenesis includes both heritable and environmental causation [38-40]. Family history was one of the most important factors in prostate cancer $[41,42]$. Previous meta-analyses observed more than twofold increased prostate cancer risk in men who have a first-degree relative with prostate cancer $[8,43]$. A family history of breast cancer has also been considered as a possible risk factor for prostate cancer $[19,26]$. A family history of breast cancer has previously been associated with prostate cancer risk in a cohort study based on the Swedish Family-Cancer Database [21]. Similarly, a cohort study conducted by Barber et al. showed that men with first-degree relatives diagnosed with breast cancer are $21 \%$ more likely to develop prostate cancer than normal individuals and men with a family history of prostate and breast cancers are also at higher risk [19]. However, several studies found no association between family history of breast cancer and risk of prostate cancer. Thomas II et al. observed that a family history of breast cancer alone was not related to increased prostate cancer risk [24]. Bai et al. reported that risk of prostate cancer was not significantly related to family history of breast cancer in China [34]. Moreover, several studies have estimated the effect of family history of breast cancer in mothers only, sisters only, and daughters only with varying results. A prospective study on 37,002 US men in the Health Professionals Follow-up Study showed that a family history of breast cancer in mothers only and sisters only was significantly associated with increased prostate cancer risk [19], and the results were consistent with those of two cohort studies $[18,26]$. We also observed a positive association between history of breast cancer in daughters 

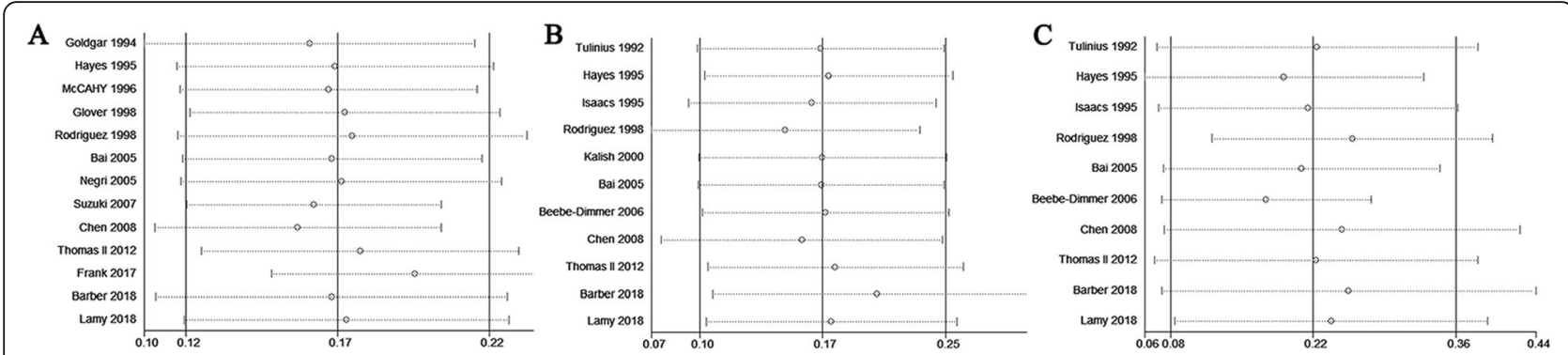

Fig. 5 Sensitivity analysis diagrams for each study used to assess the association between family history of female breast cancer and prostate cancer risk. (a. Family history of breast cancer in first-degree relatives; b. Family history of breast cancer in mother only; c. Family history of breast cancer in sister only)

only and increased prostate cancer risk in cohort and case-control studies [23, 28]. However, other studies reported no significant association between prostate cancer risk and family history of breast cancer in mothers only, sisters only, and daughters only [24, 27]. This difference between studies may be due to the study design, sample size, nationalities, or study regions. Thus, more high-quality studies are needed to assess the associations.

In the subgroup meta-analyses based on the study region, a family history of female breast cancer in first-degree relatives was associated with prostate cancer risk in Europe, America, and Asia. A family history of breast cancer in mothers only and sisters only was associated with prostate cancer risk in America, while no significant association was found in Europe and Asia. A family history of breast cancer in daughters only was not associated with prostate cancer risk in Europe, America, and Asia. However, these results need to be interpreted with caution because the number of studies reported in Europe and Asia was relatively small; thus, more studies are warranted to further investigate the potential relationships between family history of female breast cancer and prostate cancer risk in Europe and Asia. In the subgroup meta-analyses based on the study design, a family history of breast cancer in first-degree relatives and sisters only was associated with prostate cancer risk in cohort and case-control studies. A family history of breast cancer in mothers only and daughters only was associated with prostate cancer risk in cohort studies, but not in casecontrol studies. It is considered that these negative associations were attributed to the limited number of studies included in the meta-analysis.
In our analysis, we observed that men with a family history of female breast cancer have a higher risk of prostate cancer, including lethal prostate cancer. The underlying mechanisms of the associations are still unclear. A common gene alteration may be responsible for the clustering of prostate and breast cancer. BRCA1 and BRCA2 gene mutations, confirmed to be linked to breast cancer in families [44, 45], confer a 3.8- and 8.6-fold increased risk of developing prostate cancer, respectively $[14,15]$. BRCA2 carriers are associated with poor prognosis and more aggressive form in prostate cancer [46, 47]. In addition to BRCA1 and BRCA2 genes, previous studies supported the contribution of other undetermined genetic factors to the aetiology and prognosis of prostate cancer in breast cancer-prone families [48-50]. Further studies are needed to explore the mechanism of the relationship between family history of female breast cancer and lethal prostate cancer risk and provide further data on the incidence and prognosis of prostate cancer in individuals with a family history of female breast cancer.

As the number of studies increased, we could perform multiple subgroup analyses to assess heterogeneity and publication bias. To our knowledge, our study was the first systematic literature review with a meta-analysis to evaluate the relationship between family history of female breast cancer and prostate cancer risk. The large sample size is another important strength of this study. The heterogeneity and publication bias in this meta-analysis are small. Moreover, we rigorously used the GRADE approach to assess quality of evidence for the main outcome. However,

Table 5 Publication bias test for the history of female breast cancer and risk of prostate cancer

\begin{tabular}{lllll}
\hline Exposure & & Egger test & & \\
& Coefficient & $P$ & $95 \% \mathrm{Cl}$ \\
\hline First degree relatives with female BCa & 0.837 & 0.052 & -0.008 to 1.683 & 0.360 \\
History of BCa in mother only & 0.072 & 0.863 & -0.887 to 1.030 \\
History of BCa in sister only & 1.669 & 0.024 & 0.283 to 3.056 \\
\hline
\end{tabular}

BCa: breast cancer; PCa: prostate cancer 

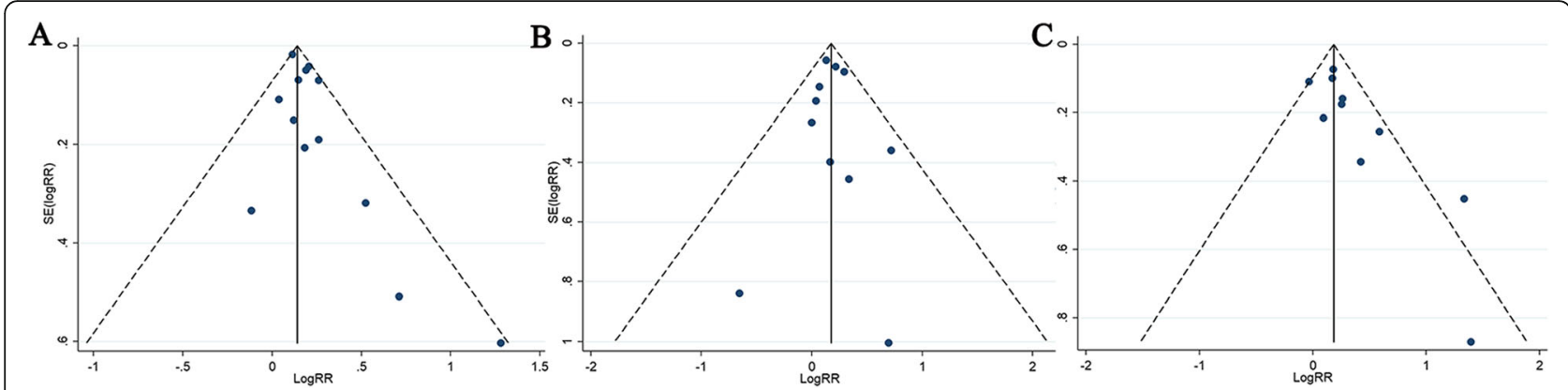

Fig. 6 Funnel plots of the studies assessing the association between family history of female breast cancer and prostate cancer risk. (a. Family history of breast cancer in first-degree relatives; $\mathbf{b}$. Family history of breast cancer in mother only; c. Family history of breast cancer in sister only)

this study has several limitations. First, there were too few studies to draw a definitive conclusion for the risk of lethal prostate cancer in men with a family history of breast cancer. More prospective cohort studies that evaluate the incidence and prognosis of prostate cancer in men with a family history of female breast cancer are needed. Second, the results showed that the risk of prostate cancer was not significant in individuals with family history of female breast cancer in first-degree relatives diagnosed with breast cancer at the age of $<50$ and $\geq 50$ years. The results need to be interpreted with caution because only two studies reported these associations in these analyses. Finally, due to the lack of relevant information in the included studies, we did not estimate the risk of early-onset prostate cancer in men with a family history of female breast cancer.

\section{Conclusions}

Therefore, the results of this meta-analysis indicate that a family history of female breast cancer in first-degree relatives was associated with an increased risk of prostate cancer, including lethal prostate cancer. These findings reinforce the importance of family history of female breast cancer in prostate cancer risk, beyond the roles of family history of prostate cancer. Further detailed work is needed to better investigate the mechanism of these associations and assess the association between family history of female breast cancer and prostate cancer progression and prognosis.

\section{Abbreviations}

BCa: Breast cancer; BRCA1: Breast Cancer Susceptibility Gene 1; BRCA2: Breast Cancer Susceptibility Gene 1; Cl: Confidence interval; Cls: Confidence intervals; HR: Hazard ratio; MOOSE: Meta-analysis of Observational Studies in Epidemiology; NOS: Newcastle-Ottawa scale; OR: Odds ratio; PCa: Prostate cancer; PRISMA: Preferred Reporting Items for Systematic Review and Metaanalysis; RR: Relative risk

Acknowledgements

Not applicable.

\section{Authors' contributions}

ZJR, QD, DHC and QZ participated in the design, data acquisition, manuscript writing, and have given final approval of the version to be published. PWR, LRL performed data analysis, data interpretation. QD and QW revised the manuscript. WRW have substantively revised our manuscript during the progress of major revision and minior revision, especially in English language improvements, and also give us many suggestions during the writing progress. All authors read and approved the final manuscript.

\section{Funding}

This work was supported by a Key Project of National Natural Science Foundation of China; Grant ID: 8177060452; This work was supported by Key Research and Development Project of Science and Technology Department of Sichuan Province, Grant ID: 2017SZ0067; and 1.3.5 project for disciplines of excellence, West China Hospital, Sichuan University, Grant ID: ZY2016104. The funding bodies had no role in the design of the study and collection, analysis, and interpretation of data and in writing the manuscript.

\section{Availability of data and materials}

All data generated or analysed during this study are included in this manuscript.

Ethics approval and consent to participate Not applicable.

\section{Consent for publication}

Not applicable.

\section{Competing interests}

The authors declare that they have no competing interests.

\section{Author details}

'Department of Urology, Institute of Urology, West China Hospital, Sichuan University, 37, Guo Xue Road, Chengdu 610041, China. ${ }^{2}$ State Key Laboratory of Biotherapy and Cancer Center, Collaborative Innovation Center for Biotherapy, West China Hospital, Sichuan University, Chengdu, China. ${ }^{3}$ Department of Radiology, Chongqing Traditional Chinese Medicine Hospital, Chongqing, China. ${ }^{4}$ Department of Evidence-Based Medicine and Clinical Epidemiology, West China Hospital, Sichuan University, Chengdu, China.

Received: 27 March 2019 Accepted: 19 August 2019

Published online: 02 September 2019

\section{References}

1. Cucchiara V, Cooperberg MR, Dall'Era M, Lin DW, Montorsi F, Schalken JA, Evans CP. Genomic markers in prostate Cancer decision making. Eur Urol. 2018;73(4):572-82.

2. Bray F, Ferlay J, Soerjomataram I, Siegel RL, Torre LA, Jemal A. Global cancer statistics 2018: GLOBOCAN estimates of incidence and mortality worldwide for 36 cancers in 185 countries. CA Cancer J Clin. 2018:68(6):394-424.

3. Cuzick J, Thorat MA, Andriole G, Brawley OW, Brown PH, Culig Z, Eeles RA, Ford LG, Hamdy FC, Holmberg L, et al. Prevention and early detection of prostate cancer. Lancet Oncol. 2014;15(11):e484-92. 
4. Leitzmann MF, Rohrmann S. Risk factors for the onset of prostatic cancer: age, location, and behavioral correlates. Clin Epidemiol. 2012;4:1-11.

5. Pettersson A, Robinson D, Garmo H, Holmberg L, Stattin P. Age at diagnosis and prostate cancer treatment and prognosis: a population-based cohort study. Ann Oncol. 2018;29(2):377-85.

6. Albright F, Stephenson RA, Agarwal N, Teerlink CC, Lowrance WT, Farnham JM, Albright LA. Prostate cancer risk prediction based on complete prostate cancer family history. Prostate. 2015;75(4):390-8.

7. Hemminki K. Familial risk and familial survival in prostate cancer. World J Urol. 2012;30(2):143-8.

8. Kicinski M, Vangronsveld J, Nawrot TS. An epidemiological reappraisal of the familial aggregation of prostate cancer: a meta-analysis. PLoS One. 2011. 6(10):e27130.

9. Eeles RA, Olama AA, Benlloch S, Saunders EJ, Leongamornlert DA, Tymrakiewicz M, Ghoussaini M, Luccarini C, Dennis J, Jugurnauth-Little S, et al. Identification of 23 new prostate cancer susceptibility loci using the iCOGS custom genotyping array. Nat Genet. 2013;45(4):385-91 391e381-382.

10. Lichtenstein P, Holm NV, Verkasalo PK, lliadou A, Kaprio J, Koskenvuo M, Pukkala E, Skytthe A, Hemminki K. Environmental and heritable factors in the causation of cancer--analyses of cohorts of twins from Sweden, Denmark, and Finland. N Engl J Med. 2000;343(2):78-85.

11. Petrucelli N, Daly MB, Feldman GL. Hereditary breast and ovarian cancer due to mutations in BRCA1 and BRCA2. Genet Med. 2010;12(5):245-59.

12. O'Donovan PJ, Livingston DM. BRCA1 and BRCA2: breast/ovarian cancer susceptibility gene products and participants in DNA double-strand break repair. Carcinogenesis. 2010;31(6):961-7.

13. Kote-Jarai Z, Leongamornlert D, Saunders E, Tymrakiewicz M, Castro E, Mahmud N, Guy M, Edwards S, O'Brien L, Sawyer E, et al. BRCA2 is a moderate penetrance gene contributing to young-onset prostate cancer: implications for genetic testing in prostate cancer patients. Br J Cancer. 2011;105(8):1230-4.

14. Leongamornlert D, Mahmud N, Tymrakiewicz M, Saunders E, Dadaev T, Castro E, Goh C, Govindasami K, Guy M, O'Brien L, et al. Germline BRCA1 mutations increase prostate cancer risk. Br J Cancer. 2012;106(10):1697-701.

15. Castro E, Goh C, Olmos D, Saunders E, Leongamornlert D, Tymrakiewicz M, Mahmud N, Dadaev T, Govindasami K, Guy M, et al. Germline BRCA mutations are associated with higher risk of nodal involvement, distant metastasis, and poor survival outcomes in prostate cancer. J Clin Oncol. 2013;31(14):1748-57.

16. Carter HB, Helfand B, Mamawala M, Wu Y, Landis P, Yu H, Wiley K, Na R, Shi Z, Petkewicz J, et al. Germline mutations in ATM and BRCA1/2 are associated with Grade reclassification in men on active surveillance for prostate Cancer. Eur Urol. 2018.

17. Na R, Zheng SL, Han M, Yu H, Jiang D, Shah S, Ewing CM, Zhang L, Novakovic K, Petkewicz J, et al. Germline mutations in ATM and BRCA1/2 distinguish risk for lethal and indolent prostate Cancer and are associated with early age at death. Eur Urol. 2017;71(5):740-7.

18. Hemminki K, Sundquist J. Brandt a:do discordant cancers share familial susceptibility? Eur J Cancer. 2012:48(8):1200-7.

19. Barber L, Gerke T, Markt SC, Peisch SF, Wilson KM, Ahearn T, Giovannucci E, Parmigiani G, Mucci LA. Family history of breast or prostate Cancer and prostate Cancer risk. Clin Cancer Res. 2018;24(23):5910-7.

20. Stang A. Critical evaluation of the Newcastle-Ottawa scale for the assessment of the quality of nonrandomized studies in meta-analyses. Eur J Epidemiol. 2010;25(9):603-5.

21. Frank C, Sundquist J, Hemminki A, Hemminki K. Familial associations between prostate Cancer and other cancers. Eur Urol. 2017;71(2):162-5.

22. MCCAHY PJ, HARRIS CA, NEAL DE. Breast and prostate cancer in the relatives of men with prostate cancer. Br J Urol. 1996;78:552-6.

23. Lamy PJ, Tretarre B, Rebillard X, Sanchez M, Cenee S, Menegaux F. Family history of breast cancer increases the risk of prostate cancer: results from the EPICAP study. Oncotarget. 2018;9(34):23661-9.

24. Thomas JA 2nd, Gerber L, Moreira DM, Hamilton RJ, Banez LL, CastroSantamaria R, Andriole GL, Isaacs WB, Xu J, Freedland SJ. Prostate cancer risk in men with prostate and breast cancer family history: results from the REDUCE study (R1). J Intern Med. 2012;272(1):85-92.

25. Mori M, Masumori N, Fukuta F, Nagata Y, Sonoda T, Miyanaga N, Akaza H, Tsukamoto T. Weight gain and family history of prostate or breast cancers as risk factors for prostate cancer: results of a case-control study in Japan. Asian Pac J Cancer Prev. 2011;12(3):743-7.

26. Chen YC, Page JH, Chen R, Giovannucci E. Family history of prostate and breast cancer and the risk of prostate cancer in the PSA era. Prostate. 2008; 68(14):1582-91.
27. Beebe-Dimmer JL, Drake EA, Dunn RL, Bock CH, Montie JE, Cooney KA. Association between family history of prostate and breast cancer among African-American men with prostate cancer. Urology. 2006;68(5):1072-6.

28. Tulinius $\mathrm{H}$, Egilsson $\mathrm{V}$, Olafsdottir $\mathrm{GH}$, Sigvaldason $\mathrm{H}$. Risk of prostate, ovarian, and endometrial cancer among relatives of women with breast cancer. BMJ (Clinical research ed). 1992;305(6858):855-7.

29. Goldgar DE, Easton DF, Cannon-Albright LA, Skolnick MH. Systematic population-based assessment of cancer risk in first-degree relatives of cancer probands. J Natl Cancer Inst. 1994;86(21):1600-8.

30. Hayes RB, Liff JM, Pottern LM, Greenberg RS, Schoenberg JB, Schwartz AG, Swanson GM, Silverman DT, Brown LM, Hoover RN, et al. Prostate cancer risk in U.S. blacks and whites with a family history of cancer. Int J Cancer. 1995;60(3):361-4.

31. Isaacs SD, Kiemeney LA, Baffoe-Bonnie A, Beaty TH, Walsh PC. Risk of cancer in relatives of prostate cancer probands. J Natl Cancer Inst. 1995;87(13):991-6.

32. Glover FE Jr, Coffey DS, Douglas LL, Russell H, Cadigan M, Tulloch T, Wedderburn K, Wan RL, Baker TD, Walsh PC. Familial study of prostate cancer in Jamaica. Urology. 1998;52(3):441-3.

33. Kalish LA, McDougal WS, McKinlay JB. Family history and the risk of prostate cancer. Urology. 2000;56(5):803-6.

34. Bai Y, Gao YT, Deng J, Sesterhenn IA, Fraumeni JF, Hsing AW. Risk of prostate cancer and family history of cancer: a population-based study in China. Prostate Cancer Prostatic Dis. 2005;8(1):60-5.

35. Negri E, Pelucchi C, Talamini R, Montella M, Gallus S, Bosetti C, Franceschi S, La Vecchia C. Family history of cancer and the risk of prostate cancer and benign prostatic hyperplasia. Int J Cancer. 2005;114(4):648-52.

36. Suzuki T, Matsuo K, Wakai K, Hiraki A, Hirose K, Sato S, Ueda R, Tajima K. Effect of familial history and smoking on common cancer risks in Japan. Cancer. 2007;109(10):2116-23.

37. Rodríguez C, Calle EE, Tatham LM, Wingo PA, Miracle-McMahill HL, Thun MJ, Heath CW Jr. Family history of breast Cancer as a predictor for fatal prostate Cancer. Epidemiology. 1998;9(5):525-9.

38. Hjelmborg JB, Scheike T, Holst K, Skytthe A, Penney KL, Graff RE, Pukkala E, Christensen K, Adami HO, Holm NV, et al. The heritability of prostate cancer in the Nordic twin study of Cancer. Cancer Epidemiol Biomark Prev. 2014; 23(11):2303-10.

39. Romero FR, Romero AW, Almeida RM, Oliveira FC Jr, Tambara Filho R. The significance of biological, environmental, and social risk factors for prostate cancer in a cohort study in Brazil. Int Braz J Urol. 2012;38(6):769-78.

40. Tse LA, Lee PMY, Ho WM, Lam AT, Lee MK, Ng SSM, He Y, Leung KS, Hartle JC, $\mathrm{Hu} \mathrm{H}$, et al. Bisphenol a and other environmental risk factors for prostate cancer in Hong Kong. Environ Int. 2017;107:1-7.

41. Liss MA, Chen H, Hemal S, Krane S, Kane CJ, Xu J, Kader AK. Impact of family history on prostate cancer mortality in white men undergoing prostate specific antigen based screening. J Urol. 2015;193(1):75-9.

42. Perez-Cornago A, Key TJ, Allen NE, Fensom GK, Bradbury KE, Martin RM, Travis RC. Prospective investigation of risk factors for prostate cancer in the UK biobank cohort study. Br J Cancer. 2017;117(10):1562-71.

43. Bruner DW, Moore D, Parlanti A, Dorgan J, Engstrom P. Relative risk of prostate cancer for men with affected relatives: systematic review and meta-analysis. Int J Cancer. 2003;107(5):797-803.

44. Palmero El, Alemar B, Schuler-Faccini L, Hainaut $P$, Moreira-Filho CA, Ewald IP, Santos PK, Ribeiro PL, Oliveira CB, Calvez-Kelm FL, et al. Screening for germline BRCA1, BRCA2, TP53 and CHEK2 mutations in families at-risk for hereditary breast cancer identified in a population-based study from southern Brazil. Genet Mol Biol. 2016;39(2):210-22.

45. Peixoto A, Santos C, Pinto P, Pinheiro M, Rocha P, Pinto C, Bizarro S, Veiga I, Principe AS, Maia $S$, et al. The role of targeted BRCA1/BRCA2 mutation analysis in hereditary breast/ovarian cancer families of Portuguese ancestry. Clin Genet. 2015;88(1):41-8.

46. Gleicher S, Kauffman EC, Kotula L, Bratslavsky G, Vourganti S. Implications of high rates of metastatic prostate Cancer in BRCA2 mutation carriers. Prostate. 2016;76(13):1135-45.

47. Cheng HH, Pritchard CC, Boyd T, Nelson PS, Montgomery B. Biallelic inactivation of BRCA2 in platinum-sensitive metastatic castration-resistant prostate Cancer. Eur Urol. 2016;69(6):992-5.

48. Song WH, Kim SH, Joung JY, Park WS, Seo HK, Chung J, Lee KH. Prostate Cancer in a patient with a family history of BRCA mutation: a case report and literature review. J Korean Med Sci. 2017;32(2):377-81.

49. Eeles RA, Kote-Jarai Z, Al Olama AA, Giles GG, Guy M, Severi G, Muir K, Hopper $J$, Henderson BE, Haiman CA, et al. Identification of seven new 
prostate cancer susceptibility loci through a genome-wide association study. Nat Genet. 2009;41(10):1116-21.

50. Kar SP, Beesley J, Amin Al Olama A, Michailidou K, Tyrer J, Kote-Jarai Z, Lawrenson K, Lindstrom S, Ramus SJ, Thompson DJ, et al. Genome-wide meta-analyses of breast, ovarian, and prostate Cancer association studies identify multiple new susceptibility loci shared by at least two Cancer types. Cancer Discov. 2016;6(9):1052-67.

\section{Publisher's Note}

Springer Nature remains neutral with regard to jurisdictional claims in published maps and institutional affiliations.

Ready to submit your research? Choose BMC and benefit from:

- fast, convenient online submission

- thorough peer review by experienced researchers in your field

- rapid publication on acceptance

- support for research data, including large and complex data types

- gold Open Access which fosters wider collaboration and increased citations

- maximum visibility for your research: over $100 \mathrm{M}$ website views per year

At $\mathrm{BMC}$, research is always in progress.

Learn more biomedcentral.com/submissions 